\title{
Stygofauna of Oman, 1 A new freshwater stygobiont Cyathura (Isopoda, Anthuridae), from interstitia of coarse wadi sediments in Oman
}

\author{
L. Botosaneanu ${ }^{1}$ \\ J.H. Stock ${ }^{2} \dagger$
}

Keywords : Isopoda : Anthuridae, stygofauna, Oman.

A well-characterized new species of Cyathura (Stygocyathura) is described from the underflow of a wadi in Oman where a large population is present. Sixteen species have been attributed to this entirely stygobiont subgenus; they are either from the Caribbean - Gulf of Mexico region, or from the western Pacific, whereas a single species has been recorded from the realm of the Indian Ocean: $C$. (S.) milloti Chappuis, Delamare \& Paulian from Réunion Island. The new species could be remotely related to $C$. (S.) milloti.

Une nouvelle espèce stygobie d'eau douce de Cyathura (Isopoda, Anthuridae) des interstices de sédiments grossiers d'un wadi d'Oman

Mots clés : Isopoda : Anthuridae, stygofaune, Oman.

Une nouvelle espèce bien distincte de Cyathura (Stygocyathura) est décrite du sous-écoulement d'un wadi d'Oman où une population considérable est présente. Seize espèces étaient à ce jour décrites dans ce sous-genre entièrement stygobie, soit de la zone des Caraibes - Golfe du Mexique, soit du Pacifique Ouest, une seule espèce étant connue de la zone de l'Océan Indien: $C$. milloti Chappuis, Delamare \& Paulian, de la Réunion, avec laquelle la nouvelle espèce pourrait avoir des relations de lointaine parenté.

\section{Introduction}

During extensive fieldwork in the frame of a 'Research Program: Biological groundwater survey of the Sultanate of Oman', sponsored by the Ministry of Water Resources, Ruwi, Oman (director: Mr. Zaher Khalid Suleimani), a Dutch/Omani team took almost 130 stygofaunal samples in wells, springs, caves, and inter-

\footnotetext{
1. Institute for Systematics and Population Biology, University of Amsterdam, Plantage Middenlaun 64, 1018 DH GT Amsterdam, The Netherlands.

2. Emeritus Professor J.H. Stock passed away (17 February 1997) short after the manuscript of this paper was prepared. This prominent carcinologist stygobiologist and biogeographer was an intrepid explorer, having organized and often headed a good number of sampling travels to various countries and islands ; in some of them I had the privilege of accompanying him. His Oman travel - the present paper bringing to light its first results - was his last one : Sic volvere Parcas!
}

stitia of stream sediments. The present paper is the first in a small series by various specialists, exposing the taxonomic results of the sampling.

A complete list of sampling stations can be found in Stock et al. (1997).

\section{Systematic part}

Crustacea: Isopoda: Anthuridea, Anthuridae

Genus Cyathura Norman \& Stebbing, 1886

Subgenus Stygocyathura Botosaneanu \& Stock, 1982

C. (S.) wadincola n. sp.

(Figs. 1-25)

Locality.- Oman stations $96-118$ and 96-119. In the middle of the stream bed of Wadi Nakhl, just past the cataract (UTM 0584648/25863664, i.e., circa $23^{\circ} 22^{\prime} 33^{\prime \prime N} 57^{\circ} 49^{\prime} 42^{\prime \prime} \mathrm{E}$ ). Two samples taken from the underflow of the wadi (= stream or river bed, which carries flash floods; sediment deposits usually poorly sorted), with the aid of a Bou-Rouch pump (see Bou 

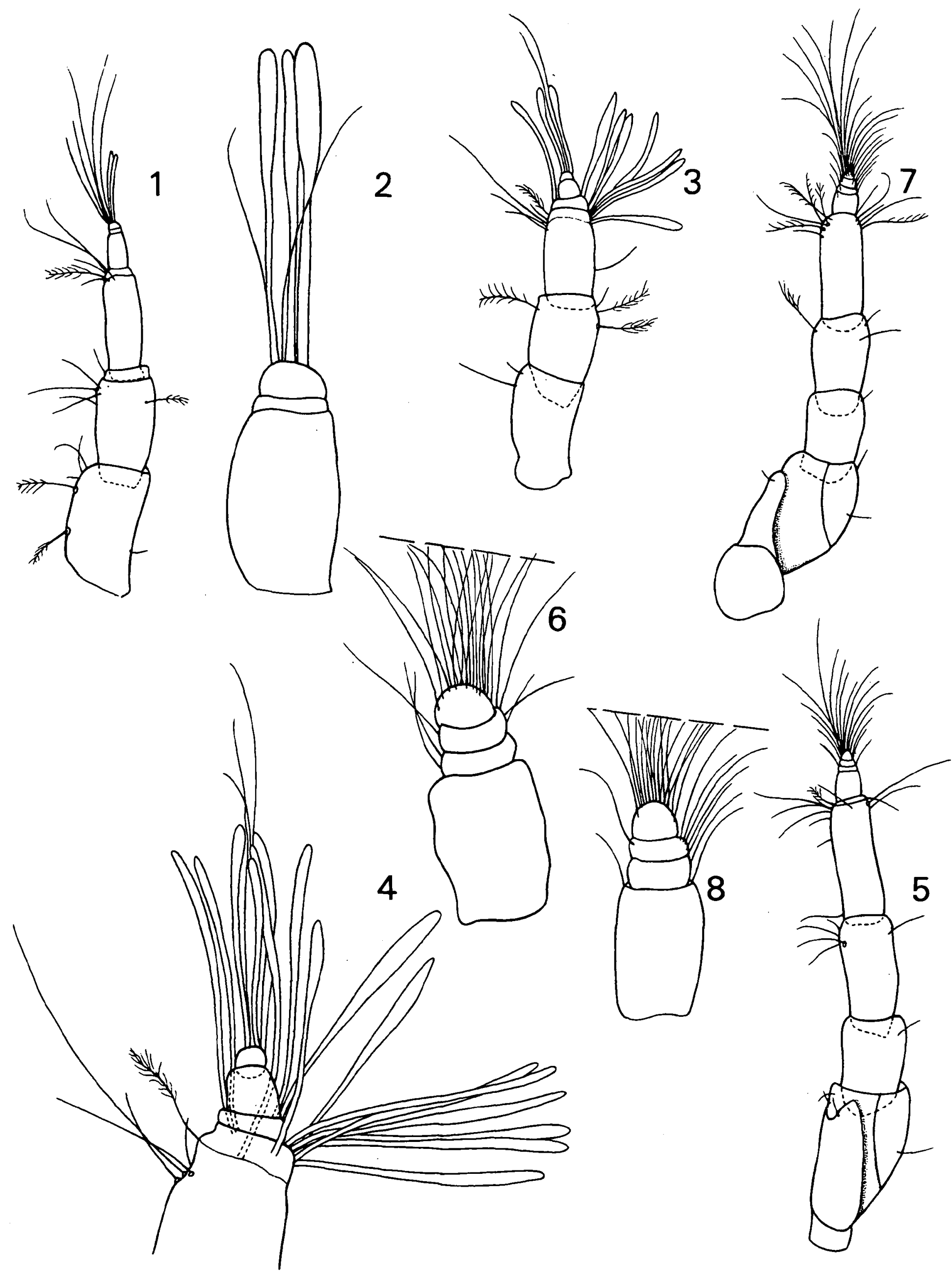

Figs. 1-8. Cyathura (Stygocyathura) wadincola $\mathrm{n}$. sp.: 1, $\uparrow$ antennula; 2 , flagellum of $\$$ antennula, long bristles not represented; 3,0 antennula; $4, \sigma^{\circ}$ antennula, distal part of third peduncular article, and flagellum; 5 , $\%$ antenna; 6 , flagellum of $\%$ antenna; $7,0^{\circ}$ antenna; 8 , flagellum of $\sigma^{\circ}$ antenna.

Figs. 1-8. Cyathura (Stygocyathura) wadincola n. sp. : 1, antennule de la $\$ ; 2$, flagelle de l'antennule de la $\$$, longues soies non figurées; 3 , antennule de $\sigma^{\prime} ; 4$, antennule de $0^{\prime \prime}$, partie distale du 3ème article du pédoncule et flagelle; 5 , antenne de la $\$ ; 6$, flagelle de l'antenne de la $\$ ; 7$, antenne du $\sigma^{\prime ;} ; 8$, flagelle de l'antenne du $\sigma^{\prime \prime}$. 


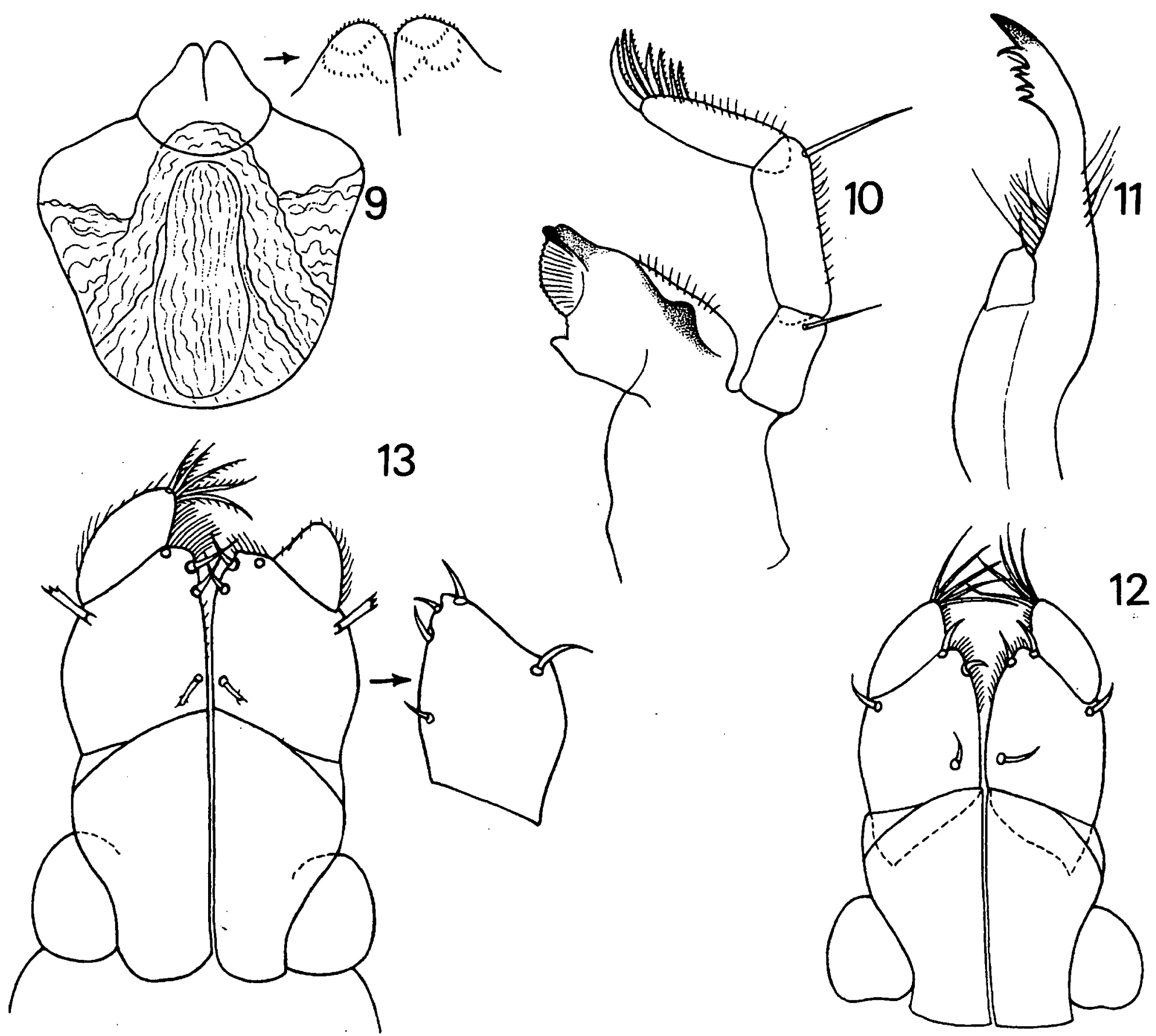

Figs. 9-13. Cyathura (Stygocyathura) wadincola n. sp.: 9, labrum, ventral, arrow pointing to its more strongly magnified apex, dorsal; 10, right mandibula; 11 , maxilla $1 ; 12$, maxillipeds of $\sigma^{*}$ holotype; 13 , maxillipeds of $\$$ allotype, arrow pointing to second "free article" of left maxilliped of a $\$$ paratype.

Figs. 9-13. Cyathura (Stygocyathura) wadincola $\mathrm{n}$. sp. : 9, labrum en vue ventrale (la flèche indique son apex en vue dorsale, à un plus fort grossissement); 10 , mandibule droite; 11 , maxillule; 12 , maxillipèdes de l'holotype 0 ; 13 , maxillipèdes de l'allotype $\$$ (la flèche indique le 2 ème «article libre» du maxillipède gauche d'un paratype $\$$ ).

1974) in gravel, at $50-60 \mathrm{~cm}$ below the sediment surface. Water temperature $33.2-35.5^{\circ} \mathrm{C}$; electric conductivity 620-627 $\mu$ S; 9 April 1996. Collected by J.H. Stock and J.J. Vermeulen.

Material.- Five $0^{\circ} 0^{\prime \prime}$ (holotype and paratypes), ten $\$ 9$ (allotype and paratypes), three post-manca specimens. Holotype and allotype partly dissected, all dissected parts in glycerin on slides. All but one specimens kept in the Zoölogisch Museum Amsterdam (ZMA Is. 202.103a-d); one paratype in the Oman Museum of Natural History, Muscat (ONHM 2605). The condition of most specimens is good, although some appendages are missing or broken.

Description.- This description is mainly restricted to those elements, that we know by experience to characterize taxa at species level. For a general description of the morphology of stygobiont Cyathura, one is referred to Botosaneanu \& Stock (1982).

Completely depigmented, eyeless. Body length $\sigma^{7}$ holotype ca. $3.65 \mathrm{~mm}$, of $\sigma^{\prime \prime}$ paratypes (all with appendix masculina) $3.1-3.7 \mathrm{~mm}$. Length of 9 allotype 5.4 $\mathrm{mm}$, of $q$ paratypes (none with oostegites) $3.3-5.4 \mathrm{~mm}$. 

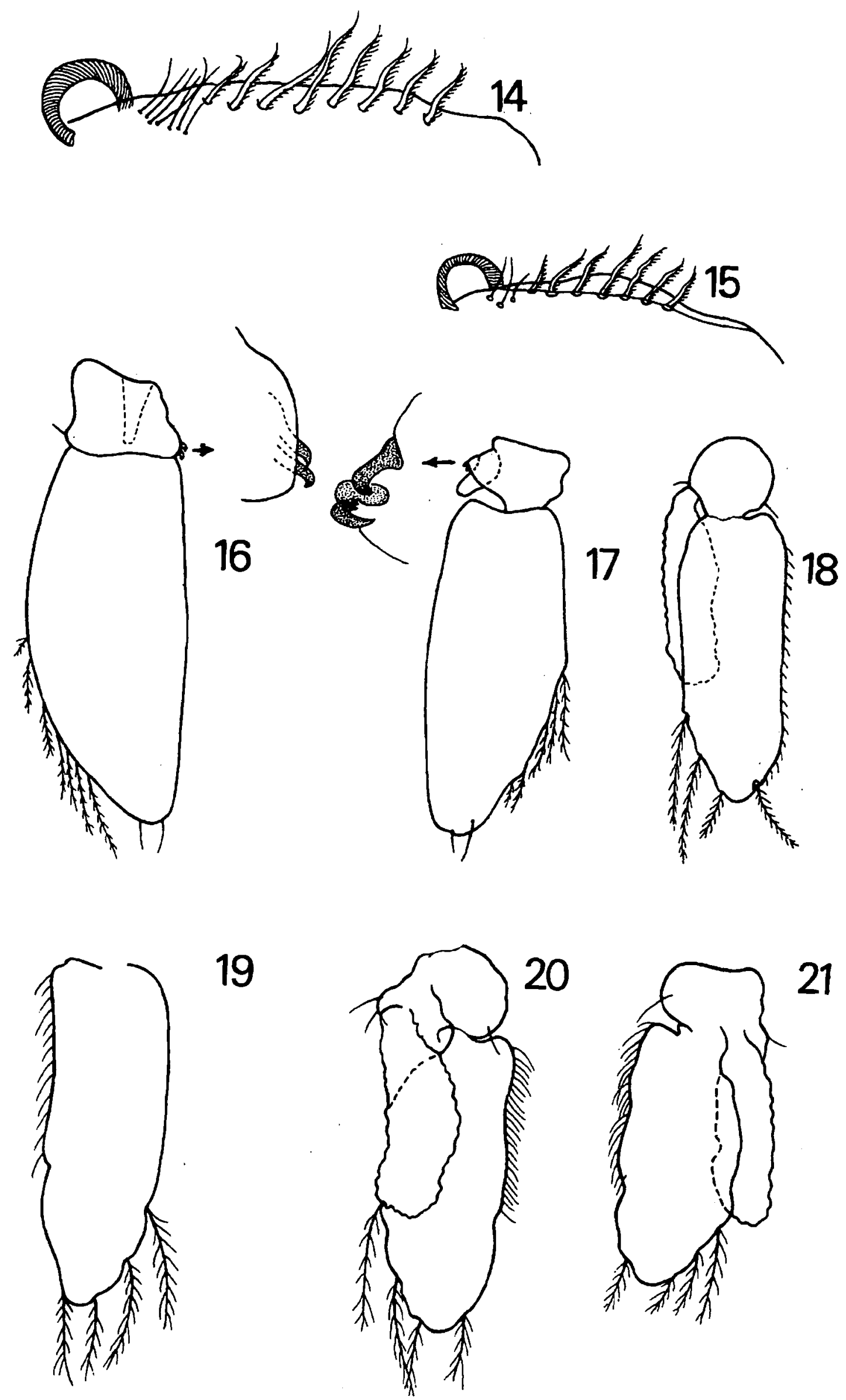

Figs. 14-21. Cyathura (Stygocyathura) wadincola n. sp. : 14-15, palmar margin of gnathopodal propodus of $\$$ and 0 , respectively; 16-17, pleopod 1, ventral, of $\%$ and $\sigma^{\prime \prime}$, respectively, retinacula of protopodite more strongly magnified; 18-21, pleopod $2 \%$, and pleopods 3-5 $\sigma^{\circ}$.

Figs. 14-21. Cyathura (Stygocyathura) wadincola n. sp. : 14-15, bord palmaire du propode du gnathopode $\$$ et $0^{\prime \prime}$ respectivement; 16-17, pléopode 1 en vue ventrale, $\$$ et $\sigma^{\prime \prime}$ respectivement (retinacula du protopodite à plus fort grossissement); 18-21, pléopode 2 de la $\$$ et pléopodes 3 5 du ơ. 
Antennula of $\%$ (Figs. 1, 2): flagellum of 3 articles, basal article considerably longer than second and third articles together. Antennula of $O^{7}$ (Figs. 3,4) with large number (at least 11 or 12) of aesthetascs, inserted at different points of the well-individualized apical zone of the last peduncular article; flagellum of 3 articles; in Fig. 4 the flagellum is completely extended, i.e., not telescoped into the last peduncular article, allowing for a good observation of the aesthetasc equipment; on the basal article, 2 aesthetascs are implanted; the much stronger second article is glabrous; apical article with the 'normal' equipment of setae and aesthetascs. It is quite possible that there is slight individual variation in the aesthetasc equipment.

Antenna of $\$$ (Figs. 5, 6) and $\sigma^{7}$ (Figs. 7, 8) as illustrated. Flagellum 4-articulate.

Labrum illustrated (Fig. 9). Mandibles (Fig. 10): second and third articles of palp twice as long as first article; third article distally with 7 pectinate setae. First maxilla illustrated (Fig. 11): Maxilliped $\sigma^{\prime}$ as in Fig. 12 ; there are only 4 setae, all very short, on the second "free article"; two of these implanted on either side of the protruding interno-distal angle, the third seta arising much more basally, near (but not on) the internal margin; 5 pectinate setae on apex of last article. The left maxilliped of the $\$$ allotype (Fig. 13) has a strongly anomalous last "free article"; there are 3 setae near the protruding interno-distal angle of the second article (this is the normal number as confirmed by examination of the normally developed maxilliped of a $\$$ paratype).

There is apparently some sexual dimorphism in the palmar margin of the gnathopodal propodus (Figs. 14, 15). The pereiopods were not found worth description or illustration. Structure of pleon as in all Cyathura (Stygocyathura) .

Pleopod 1 (Figs. 16, 17) as illustrated; note that there are 2-3 retinacula on the protopodite, unfortunately ignored in some earlier descriptions of members of the subgenus Stygocyathura; the endopodite is reduced to a small lobe. With the exception of pleopod $20^{\circ}$, the pleopods 2 to 5 are fundamentally similar in the two sexes: exopodites lacking any trace of bipartition, but (always?) with a distinct notch on the external margin, and equipped with only 4 plumose setae, endopodites distinctly shorter.

Pleopod $2 \sigma^{7}$ (Figs. 22, 23): exopodite roughly similar to that of the $\$$, and to male pleopods 3 to 5 , whereas the exopodite is distinctly longer; appendix masculina highly characteristic: its apical part is clearly turned laterad; the long stem has anteapically on the dorsal side a distinct, rounded swelling, which conti- nues for a while basad; there are 2 marked apical apophyses, the dorsal one being a simple conical protuberance with blunt tip and obliquely directed downwards, and the ventral one shaped like a fishing hook, being broad basally, then forming a slender, gently curved appendage directed downwards, and whose terminal part is a strong point directed upwards.

Uropods (Fig. 24) with narrow, but not just baculiform, exopodite, of the type previously described as "narrowly foliaceous".

Telson (Fig. 25) with complete set of 6 apical setae, which are comparatively very short: even those of the longest pair do not attain one-third of the length of the telson.

Remarks.- The specific name is derived from wadi (= non-permanent river bed) and the Latin word incola (= inhabitant).

From all points of view $C$. wadincola is a typical member of the subgenus Stygocyathura Botosaneanu \& Stock, 1982. Presently, 16 species are known in this subgenus (Botosaneanu \& Stock 1982, Botosaneanu 1986, Wägele et al. 1987, Wagner 1990). A compact group of 11 taxa inhabits the Caribbean - Gulf of Mexico zone; 4 species are known from the western Pacific; and only a single species, $C$. (S.) milloti Chappuis, Delamare \& Paulian, 1956, is recorded from Réunion Island, in the realm of the Indian Ocean. The subgenus Stygocyathura clearly is an element belonging to the "legacy of Tethys" (Por 1989).

C. wadincola $\mathrm{n}$. $\mathrm{sp}$. is clearly distinguished by a combination of several characters in the appendages already known to offer more or less reliable distinctions in this (sub)genus: number of articles of $\sigma^{7}$ and $q$ antennular flagellum; very rich equipment of aesthetascs on the last peduncular article of the $\sigma^{\prime \prime}$ antennula; proportions of the articles of the mandibular palp; chaetotaxy of the second "free article" of the maxilliped (with what seems to be sexual dimorphism); strongly reduced endopodite of pleopod 1; setal ornamentation of pleopodal exopodites reduced to 4; proportions of the constitutive parts of the uropod; telson with the complete set of 3 pairs of apical setae, which are short (even the longest setae). Most distinctive is the second male pleopod, with its narrow, elongate endopodite, and with an appendix masculina of complex shape, somewhat resembling that of $C$. (S.) milloti, a much smaller species from which $C$. (S.) wadincola differs in several other respects (which don't exclude the possibility of some remote kinship; see Wägele (1985) for considerations about relationships in Cyathura based on the structure of the appendix masculina). 

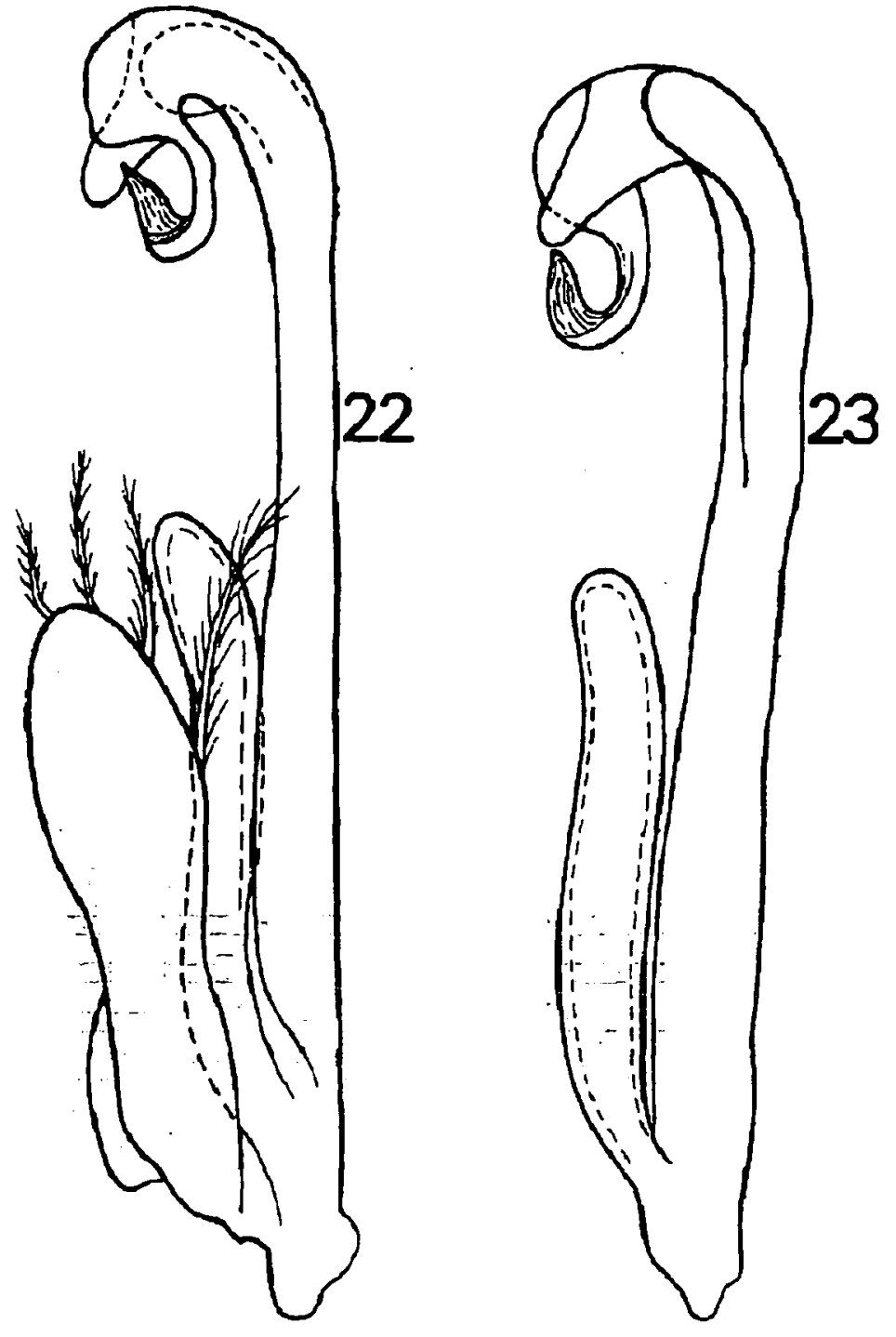

Figs. 22-23. Cyathura (Stygocyathura) wadincola n. sp., pleopods 2 of ơ: 22, ventral; 23, dorsal, exopodite omitted.

Figs. 22-23. Cyathura (Stygocyathura) wadincola n. sp., pleopode 2 of $\sigma^{\prime \prime}$ (22 en vue ventrale; 23 en vue dorsale, sans l'exopodite).

\section{Acknowledgements}

The fieldwork in Oman was strongly supported by the Research Department of the Ministry of Water Resources, Ruwi.

\section{References}

Botosaneanu L. 1986. - Isopoda: Anthuridea: 428-433. In L. Botosaneanu, ed., Stygofauna Mundi E.J. Brill / Dr. W. Backhuys, Leiden.

Botosaneanu L. \& Stock J.H. 1982. - Les Cyathura stygobies (Isopoda, Anthuridea) et surtout celles des Grandes et Petites Antilles. Bijdr. Dierk., 52 (1): 13-42.

Bou C. 1974. - Les méthodes de récolte dans les eaux souterraines interstitielles. Ann. Spéléol, 29 (4): 611-619.

Chappuis P.A., Delamare Deboutteville Cl. \& Paulian R. 1956. Crustacés des eaux souterraines littorales d'une résurgence d'eau douce à la Réunion. Mém. Inst. Sci. Madagascar, (A) 11: 51-78.

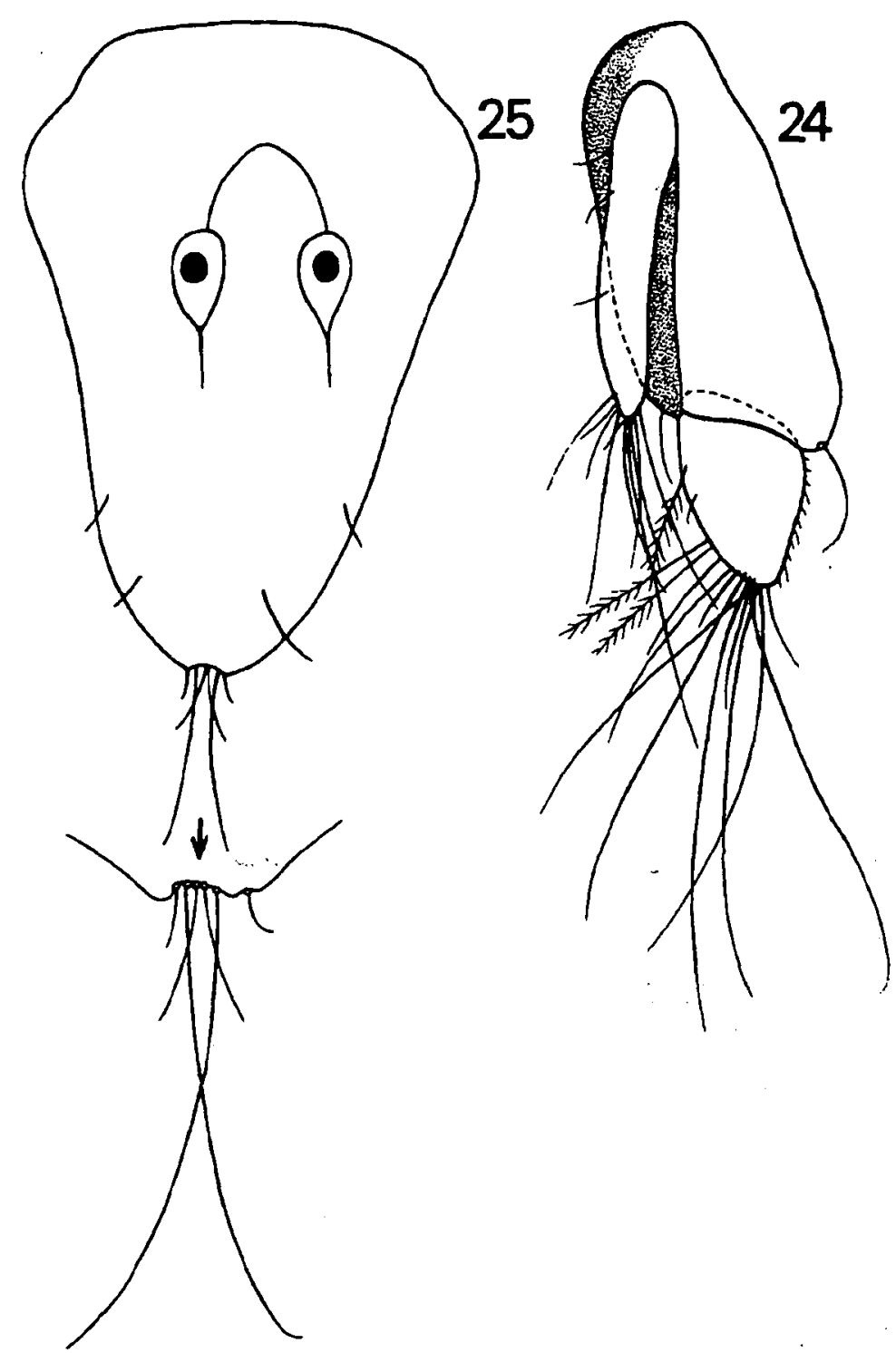

Figs. 24-25. Cyathura (Stygocyathura) wadincola n. sp. : 24, left uropod, $\$$ allotype; 25 , telson, $\$$ allotype, apex more strongly magnified.

Figs. 24-25. Cyathura (Stygocyathura) wadincola n. sp. : 24, uropode gauche, allotype $\$ ; 25$, telson, allotype $\$$ et son apex à plus fort grossissement.

Por F.D. 1989. - The legacy of Tethys: an aquatic biogeography of the Levant: Kluwer Academic Publishers, Dordrecht, etc.

Stock J.H., Vermeulen J.J. \& Mutey A. 1997. — Research program: Biological groundwater survey of the Sultanate of Oman - List of sampling stations March-April 1996. Versl. techn. Gegevens Inst. Syst. Pop. Biol., $\mathbf{N}^{\circ} 71: 1-15$.

Wägele J.W. 1985. - On the Tethyan origin of the stygobiont Anthuridea Curassanthura and Cyathura (Stygocyathura), with description of Curassanthura canariensis n. sp. from Lanzarote (Crustacea, Isopoda). Stygologia, 1 (3): 258-269.

Wägele J.W., Coleman O. \& Hosse U. 1987. - Two new hypogean species of Cyathura from Melanesia (Crustacea, Isopoda, Anthuridea): further Tethyan relicts? Stygologia, 3 (1): 89-106.

Wagner H.P. 1990. - The stygobiont isopods of the genus Cyathura in the Dominican Republic (Crustacea; Isopoda; Anthuridae). Bull. zool. Mus. Univ. Amsterdam, 12 (10): 145-158. 